\title{
Young people, future hopes and concerns in Finland and the European Union: classed and gendered expectations in policy documents
}

\author{
Minna Nikunen \\ Senior Researcher \\ School of Social Sciences and Humanities \\ 33014 University of Tampere \\ Finland \\ minna.nikunen@uta.fi
}

This is an Accepted Manuscript of an article published by Taylor \& Francis in Journal of Youth Studies on 22/11/2016, available online: http://dx.doi.org/10.1080/13676261.2016.1260693.

Received 15 December 2015

Accepted 10 November 2016

\begin{abstract}
In this article, I examine the ways in which governing bodies at the Finnish national and also European Union levels talk about young people and our shared future in Finland. I use their youth policy documents as material for critical discourse analysis. My argument is that, besides presenting visions of a desired future, these papers also produce and reproduce divisions between young people that reflect gender and class positions. Young people are divided into those who have potential, those who will take care of others' needs, and those who are at risk of marginalisation. I also argue that the Nordic policy tendency to conceive of youth as a resource rather than as a problem is not consistent. Finnish youth policy has changed, firstly because of the changing economic environment - the politics of austerity and secondly because of Europeanisation.
\end{abstract}

\section{Introduction}

When young people are talked about, they usually represent the future, either as a promise or as a source of worry (e.g. White \& Wyn 2013; France 2007). In order to examine the ways in 
which governing bodies talk about young people and our shared future, I analyse their youth policy documents as data. The hopes and fears expressed in these bodies' policy documents usually relate to youth employability; more specifically, they refer to education, work and employment. The focus of this article is on the national Finnish level but EU documents are also inspected in relevant contexts. Youth policy here is understood as a form of social policy targeting young people (see Wallace \& Bendit 2009).

Clare Wallace and Rene Bendit (2009) have found that some EU countries focus in their youth policies on the young as a resource, while others present them as a problem. They place the Nordic countries in the former category, while for example the UK and Ireland represent the latter. Nordic youth policies target all young people, not just problem cases, and resources are distributed to all. Wallace and Bendit call this model the 'universalistic youth policy regime', and dub the focus on problem youth the 'community-based youth policy regime'. Intermediate models are 'protective youth policy regimes' (for the promotion and support of the young) and 'centralised youth policy regimes' (created only in response to European initiatives).

Wallace and Bendit (2009) argue that the European Union plays only an advisory role in relation to national politics, and does not address important problems such as unemployment. However, economic crises and the Europeanisation of youth policy - making it more coherent among EU member countries - may have changed the situation. Nevertheless, there are many references to EU and European Commission (EC) documents in recent Finnish youth policy documents, especially in the context of employment and education.

In this article I focus not so much on changes in youth policies, but more on changes (and continuities) in the ideas about youth employment behind the policies. I examine governing talk about the future in the light of feminist analyses of the new economy, neoliberalism and the new austerity (Adkins 2008, 2015; Coleman 2016; McDowell 2012; Berlant 2011). These ideas relate to economic fluctuations, class and gender, and also to changes in the affectual environment (especially Berlant 2011; Coleman 2016) or structures of feeling (Clarke \& Newman 2012). These analyses reflect the political environment, namely neoliberalism, which is the context of expectations surrounding young people and youth policies. ${ }^{\mathrm{i}}$. The Finnish case is that neoliberal capitalism is getting stronger, while social-democratic capitalism is losing its stronghold (and protectionist capitalism is gaining ground in the form of nationalist populism) (Walby 2011; Nikunen 2013 and 2016). 
My argument is that, as well as presenting visions of a desired future, youth policy papers also produce and reproduce divisions between young people. While the explicit aim presented in youth policy documents is inclusion and equality, they can also cause exclusion and further inequalities. Young people's futures are classed and gendered (and often also ethnicised, nationalised and localised), for instance by differentiating between their potentials. Different bodies are placed in different spatio-temporal positions, and their abilities to be mobile and gain value are anticipated. In this article I focus on ruptures in good intentions - the possibilities of inequality that are built into neutral discourse about equality and fulfilment for all.

\section{Young adults and employment in the Finnish context}

As elsewhere in the EU, youth unemployment is high in Finland. One in six 15-24-year-olds was out of employment or education in June 2014, and one in ten 25-34-year-olds was registered unemployed (OSF 2014). Those defined as 'marginalised' or socially excluded i.e. having no vocational training, and being out of employment or education - represented 5\% of 15-29-year-olds in 2011 (Myrskylä 2011).

The number of those marginalised has not actually grown since the 1990s in Finland (Myrskylä 2011). However, discourses on youth vulnerability, lack of citizenship and at-risk youth without entrepreneurial skills have intensified among policymakers in developed countries (Kelly 2006; Foster \& Spencer 2011; McLeod 2012). Moreover, working-class career paths have not changed so dramatically, although the chances of finding a permanent job have become more uncertain. It has been claimed that it is mainly middle-class youth, and their parents, who are worried that higher education no longer guarantees good employment prospects (Tolonen 2005; Skeggs 2004).

The employment situation is difficult for young people, and worries about the future are justified. But not all worries relate to all young people or accurately reflect recent changes. Indeed, sometimes the concerns represented in youth policies reflect not so much a wish to help the young as a desire to make a better future for others. In the new economy, this better future is seen though a neoliberal lens, and is defined by government elites. Young people are said to be future adults or people-in-the-making (Foster \& Spencer 2011). They represent the futurity in the present. 


\section{Futurity, employability, gender and class}

Lisa Adkins (2008) has stated that in post-industrial capitalism one's value as a worker, or the value of one's work, does not simply stem from the capacities one has acquired. The futurity, or future promise, of what one is expected to do and achieve is more important than what you are already able to do or have done. The value of one's work depends on expected gain, and so does the value of the worker.

In education policy this potential is reflected in the use of the term 'employability' instead of 'employment'. This refers to the idea that formal education - learned skills and qualifications - is not enough for employment, and one has to do more: to learn skills outside the curriculum, and to present oneself as having the sought-for potential (e.g. Harvey 2001). It has been claimed that employability talk is used to mask the existence of advantages outside and before schooling, such as bodily capacities, middle-class cultural and economic capacities, and the ways that gendered assumptions affect the process of employment (ibid; Morley 2001). In this sense, 'employability' is how one is able to perform not only in specific work tasks, but also in the imagined future: it is about 'futurity'.

Joseph Borlagdan (2015) states that in field(s) of employment, different capitals provide employability, while the lack of them positions young people in situations that demand flexibility and innovation and may even cause 'symbolic violence'. For instance, being ethnically other is a lack in the field of high-tech employment. There is a game (or games) of employability that one is required to play in order to achieve the promised goal of employment; however, playing the game requires a sense of the game (social and cultural capital), recognition as a competent player, and recognition of one's achievements/capacities as legitimate. This requires that one's body fit into the game played on the field (Bourdieu 1990; McNay 1999; Adkins 2004).

These diverse ways to achieve marketable capitals explain why women and working-class people's increased opportunities to gain capacities, skills and qualifications have not resulted in their economic success (Adkins 2008). In Finland, despite the social-democratic ideals of education, social mobility has been decreasing in recent decades (Paananen et al. 2012; Erola 2012). Additionally, a recent study on gender segregation in the employment of higher- 
education graduates reveals that men find employment faster after graduation than women. Furthermore, men are employed in higher positions and receive permanent contracts more often than women (Vuorinen-Lampila 2014). Thus the group that has benefited from equal access to education in the UK, middle-class women (McDowell 2012), is not doing so well in Finland.

The ideas of employability and futurity are easily related to higher education, international mobility and global competition (see Nikunen 2013 and 2016; Yoon 2014). Competition in the global market is one of the main concerns of governing elites and policymakers in Finland (e.g. Kantola 2006). However, there is also a concern about Finland's ageing population and weakening dependency ratio (e.g. Ruotsalainen 2013); there should be taxpayers, people who are employed, in the future too. There should also be people who shoulder caring responsibilities and infrastructures (Nikunen 2013). In addition to entrepreneurial (e.g. Kelly 2006) and international motivations, young people are required to become worker citizens to meet the needs of the labour markets (Pehkonen 2013). Thus I argue that ideas about the 'old economy' persist alongside those about the new economy. It might be that austerity politics is strengthening that trend (while creating new ones).

Nonetheless, in this paper I will argue that youth policies - at least on the surface level present all young people as having bodies fitted to anything, and encourage optimism even when times are austere. However, the "pain" is not shared equally, and cuts affect different people in different ways, thus "new landscapes of inequality" are likely produced. The public sector is seen as a waste and promises of growth can be seen in private enterprise (Clarke \& Newman 2012).

\section{Data and analysis}

In my analysis, I use youth policy documents from Finnish national government bodies and the EU in some cases. The criteria for selection were that the documents must 1) focus on employment and education, ${ }^{\mathrm{ii}}$ and 2) show an interactive relationship between national and EU policy. Beside interaction with EU, the Finnish documents contain messages to lower levels of youth policy, social policy and education. The focus of the article is more on the national than the EU level. However, EU documents are emphasised in the discussion of mobility, since this is the area over which the EU is most influential and where there is concrete 
cooperation between EU states, such as the Erasmus programme. In the discussion of Finnish labour market demands and education, I focus on Finnish data, since these problems are tackled at a national level.

The documents are these: 1) Green Paper on the Learning Mobility of Young People by the European Commission (2009); 2) Green Paper on Learning Mobility: Contribution by CIMO, Centre for International Mobility, Finland (2009); 3) the European Commission's Youth on the Move: An Initiative to Unleash the Potential of Young People to Achieve Smart, Sustainable and Inclusive Growth in the European Union (2010); 4) the Ministry of Finance's Labour Markets of the Young: How Could Youth Employment Be Enhanced? (2010); and 5) Youth Guarantee: Content and Aims by the Ministry of Employment and the Economy (TEM) (2013). The first three documents are concerned with international mobility, the fourth with education and employment, and last with the Youth Guarantee.

In the analysis, I first draw a picture of general tendencies in conceptions of youth, work and the future in these documents, utilising critical discourse analysis. Critical discourse analysis requires an analysis of intricate relationships between text, talk, cognition, power, society and culture (van Dijk 1993). It does not restrict interpretations of what is happening to the data under analysis. There can, and should, be references outside the data: what is known about the phenomena, existing ideologies, actors and their power relations, and existing discourses. I focus on issues of power and ideology which are in the analysis inspected from the point of view of recent feminist discussions of the 'new economy' and the affectual environment it has created.

Secondly, I map out what spatial choices and actions are preferred, asking what one should not do and which groups are considered to have problems with the preferred action. I focus on examining ways in which differences between young people are written about and how young people are categorised. I also track the actions and features attributed to different young people, applying ideas of membership categorisation analysis (Sacks 1972). As often within the tradition of critical discourse analysis, the analysis is not simply data-driven, but is in dialogue with the aforementioned theories.

Policy documents are often socially neutral at first sight. According to Wallace and Bendit (2009, 499), in EU countries youth politics, gender and ethnicity are seldom addressed directly. Therefore, instead of explicit categorisations, I track actions and features that are conventionally attached to known identity membership categories (see Sacks 1972; Watson 
1983). Thus I focus on passages where it is possible to read the text as referring to, or addressing, certain groups of young people. In other words, I have selected from the data passages that provide materials for criticism - ruptures in class and gender neutrality, and in the Nordic idea of 'the young as a resource'.

I present my findings starting with the main discourses I have found, and then move on to inspect them more closely, addressing their classed and gendered aspects.

\section{Discourses on young people}

In recent years, we have witnessed a gradual change in the way that governing elites talk about young people and their future. This is mainly due to economic changes and setbacks in the new economy, and the declining optimism wrought by the new economy and the 'creative class'. Some authors write about '(new) austerity', referring to a shift in capitalist politics from an emphasis on growth and investment to one on recession and public-sector cuts (e.g. Adkins 2015; McDowell 2012). Thus being worried about young people might now be more common than believing in their creative potential, although these ways of conceptualising youth and the future coexist. However, in this paper I will argue that these concerns are different for different young people.

I use Lauren Berlant's (2011) concept of 'cruel optimism' to emphasise that some future visions offered to the young can be unrealistically optimistic for some. The optimistic promise - a cluster of desires - is not easy for all to achieve or maintain, and it can be toxic and affect you in ways that you did not anticipate. It also deceives those who have difficulty finding and maintaining their footing 'in worlds that are not there for them' (McCabe 2011). Indeed, for the sake of our shared future, elites also present other paths to happiness - or at least paths to avoid unhappiness. In times of austerity these visions reflect more pessimism, although this pessimism can be termed 'hopeful pessimism': even though the future is grim for young people on average, you might be lucky (Coleman 2016).

These different emphases are also reflected in the three main discourses about young people, work and education I have mapped from the policy documents (see Table 1). The first discourse relates to the idea of youth as a resource: mobility and internationalisation are seen as key to improve the employability of young people. In the second, there is a mixed discussion of young people as both a resource and a problem: young people should get the 
right education in order to meet labour market demands. In the third, youth are seen as a problem, based on a discourse of marginalisation. In the following pages I will examine these discourses further.

\section{Employability: mobility, internationalisation and creativity}

In modern society, success stories are about social mobility. Mobility is a key to success in late-modern societies such as the new capitalism too. However, the current political agenda is not about social mobility, but about being mobile as a social actor, a worker in space and time, in relation to social locus (Thrift 2005; Skeggs 2004). In youth policies, concrete or spatial mobility is often presented as a central way to gain employability (Yoon 2014). However, not every kind of mobility is good for employability, and not every mobile person can turn their mobility into employability and economic capital.

In 2009, the EC paved the way for a common youth policy by distributing its Green Paper on Youth Mobility to relevant political bodies in order to gather national responses. In Finland, CIMO was consulted. In the EU, a green paper is a tentative government report and consultation document on policy proposals for debate and discussion, without any commitment to action - the first step in changing the law. Green papers may result in the production of a white paper. In this case there was no white paper, but in 2010 the EC introduced Youth on the Move: An Initiative to Unleash the Potential of Young People to Achieve Smart, Sustainable and Inclusive Growth in the European Union. Finland's Ministry of Education used this initiative in its formulation of Finnish youth policies in Child and Youth Policy Programme 2012-2015.

The EC's mobility documents have a competitive and neoliberal edge, although on the other hand they also combat xenophobia and promote a greater understanding of other cultures (Nikunen 2013). The aforementioned 2010 initiative states: 'Europe's future prosperity depends on young people' (EC 2010). The EC uses the word 'employability', while the Finnish authorities prefer 'employment'. The common goal seems to be promoting the mobility of the young and those who work with them - decision makers have already reached a consensus:

There is consensus among many decision makers that learning mobility is good for young people. However, the benefits of learning mobility may not be sufficiently 
understood among young people themselves. A number of factors may contribute to keeping many young people from even considering a stay abroad: time pressure to finish their studies or training, jobs, lack of funding, lack of language skills and intercultural knowledge, as well as a general reluctance to leave 'home'. Young people will be more open to mobility if the benefits of learning mobility are better explained to them. (EC 2009, 7, my emphasis)

Young people should understand that completing their studies on time or getting a wage does not enhance their employability: immediate rewards and short-term perspectives are not beneficial, since one should invest in one's futurity (Adkins 2008; Reay 2004). Poor language skills, lack of intercultural knowledge and reluctance to leave 'home' are also presented as features that are typical of young people with mobility attitude problems, which they should overcome in order to become valuable mobile subjects. This miscomprehension can be understood as a classed feature: a lack of cultural resources, an overly rigid reading of the rules of the educational game, and attachment to the local are often attributed to workingclass youth. Furthermore, what is 'home' to a cosmopolitan subject or 'European citizen'? Is this not a pathetic position, a sign of giving up the promise of the good life, an inability to embody modernity (see Skeggs 2004)?

In Finland, CIMO (2009) presents mobility as an opportunity that should be available to all, as demonstrated in the tone of its universalist youth policies. All young people should be encouraged into education or work abroad, even the unemployed and those in vocational training:

Learning mobility should gradually be included as a formal part of national and local school curricula, university degree programmes, and in the work plans of youth services. Otherwise, it will be difficult to win widespread acceptance for learning mobility - or sufficient resources for full-scale learning mobility.

Mobility should be available for all. We need different kinds of mobility: there are no one-size-fits-all solutions. (...) Current mobility instruments should be evaluated to assess how they respond to the needs of different target groups, and whether new forms of mobility are needed. In particular, we should further develop methods and approaches for internationalisation at home. (CIMO 2009, 1) 
The surface-level inclusivity of this discourse creates the opportunity for cruel optimism (Berlant 2011). It emphasises that the possibility of future happiness is available for all who do as required. Thus young people become responsible for their own fate. However, the EU document reveals the characteristics that one must shed in order to be a mobile subject. It requires a reflexive reworking of values for working-class youth, who according to studies are more attached to locality than middle-class youth (e.g. Tolonen 2005; Allen \& Hollingworth 2013). CIMO is simultaneously more inclusive and less demanding than the $\mathrm{EC}$; you can become international at home, which is referred to without quotation marks.

The documents are written in a gender-neutral way, and mobile subjectivity seems to be open to middle-class young women at least. Indeed, the EU initiative Youth on the Move sees young people as having good potential to be mobile, since they do not yet have family responsibilities (EC 2010, 10). However, the same document also reveals why it is so valuable to be mobile in education: those who are mobile as students will become mobile as workers. Later on, family responsibilities will matter and those burdened by them - or perceived to be burdened - will not benefit from their investments.

The majority of 'mobile' people in the EU are between 25 and 34 years old. This age group tends to have better knowledge of languages and fewer family obligations. (EC $2010,10)$

Learning mobility is an important way in which young people can strengthen their future employability and acquire new professional competences, while enhancing their development as active citizens. It helps them to access new knowledge and develop new linguistic and intercultural competences. Europeans who are mobile as young learners are more likely to be mobile as workers later in life. Employers recognise and value these benefits. (EC 2010, 10)

These documents somewhat reflect a gendered conception of mobility, coding new creative heroism as masculine (see Adkins 2008). This is partly because male-dominated professions are more mobile than female-dominated professions, and women travel with their spouses more often than men (Nivalainen 2010). However, the idea that men are more mobile is partly a stereotype (Ravenstein 1985 cited by Dumitru 2014, 204). According to recent emigration statistics, Finnish women are more likely to go abroad than men (Official Statistics Finland 2013). Learning mobility is also more common among women than men 
(Garam 2014). Still, it seems that the international capacities acquired by young women do not translate into international career success as well as those of men do (Nivalainen 2010).

While young women's learning mobility is presented as natural, by contrast, talk about slightly older women assumes that they have problems with professional mobility because of their family responsibilities (e.g. Nikunen 2013). It is interesting that young people between 25 and 34 years old are seen as having no family obligations. Even though the median age for having a first child is high in Finland, it is still only 28 for women and 30 for men (Official Statistics Finland 2013). It is also more common for those with less education to have a child at a younger age than for those with higher educational levels (Official Statistics Finland 2013). Accordingly, the young people referred to as being without family responsibilities more likely represent middle-class persons than working-class, and are more likely men than women.

However, not all mobility is good. Young Europeans - at least those with futurity - who travel abroad should come back. Indeed, it seems that in this discourse, national background disappears and all young people are European. The next extract deals with labour shortages and reveals the kind of workers that are valuable for the future:

Facing future labour shortages, Europe needs to retain as many highly skilled workers as possible and also attract the right skills for the expected increase in labour demands. Special efforts will be needed to attract highly skilled migrants in the global competition for talent. [...] As certain professions see too many Europeans emigrating and too few third- country immigrants coming in, policies should address this. This includes $[\ldots]$ raising the attractiveness of jobs in professions which see brain-drain (e.g. scientific and medical professions) and identifying within the New Skills and Jobs initiative those occupations with shortages to which young talent within and outside the EU should be attracted. (EC 2010, 13-14, my emphasis)

In the context of learning mobility, future labour shortages mean shortages of highly skilled workers, not care professionals or cleaners. A brain drain is a threat, not a 'heart drain' of emotional workers or 'hand drain' of body workers (see Dumitru 2014). Scientific and medical professions are mentioned as examples of brain drain.

Employability takes better hold on certain bodies than others; some mobile bodies are recognised as international and mobile, while others may be misrecognised as immigrants or 
spouses. Even feminists can conceive of third-world educated women as a 'care drain' and not recognise the brain drain they cause (Dumitru 2014). When combined with mobility, the value of the future worker is based on future potential. The brain drain is a corporeal metaphor that is sometimes conceived as gendered, as it values some skills but does not acknowledge others, and defines some sectors as economically productive while excluding sectors such as welfare and social reproduction (Dumitru 2014).

Optimism can be cruel if one has a body to which the value of mobility does not attach itself as well as it does to other bodies. There are many young people who put their hopes in mobility but do not gain any material rewards. One must first fit the requirements of the category of 'mobile youth' who have no family responsibilities and no attachment to locality, who understand when the regulations should not be followed, and who are at home being European. Furthermore, they should have futurity: as an adult one should be a skilled and mobile worker in a profession that requires brains. These are features that suit the categories 'middle class' and 'man' better than 'working class' and 'woman'.

\section{Employment: capacities needed in labour markets}

Even though the demand for 'brains' and mobility seems prevalent, the future is no longer represented in terms of global fast-track growth and innovation, even in mobility documents. In times of austerity, optimistic ideas about youth and the future have turned to pessimism (Coleman 2016). Worries about the ageing population, growing unemployment and at-risk youth keep the concerns of the 'old economy' alive. A new feature may be that the private sector is seen as the expert on the capacities young people need for employment (Robertson $\&$ Dale 2013). These problems are mainly tackled on a national level, although the worries are shared by many EU countries.

In Finland, the clearest example of concern about young people getting the right education is the Ministry of Finance's (2010) document Labour Markets [sic] of the Young: How Could Youth Employment Be Enhanced? It is a response to the aforementioned 2008 EU initiative New Skills for New Jobs, and it tackles labour shortages somewhat differently than the EC's Youth on the Move. New Skills for New Jobs sets out to improve the anticipation of future skills needs, develop a better match between skills and labour market needs, and bridge the gap between education and work. In its English abstract the document states that it analyses 
'the youth employment situation and assesses current and new labour market and education policy measures, intended to support youth employment' (Ministry of Finance 2010).

According to the document, there are four main obstacles to the integration of young people into the labour market: 1) drop-outs from basic education, 2) suspensions and noncompletions of education, 3) paid work while in education, which lengthens completion times, and 4) the relationship of education and location with employment demands. In the context of mobility, concern about completing education on time is presented as a misapprehension; here it is presented as a rule. The groups of young people to whom the message is addressed seem to vary, from those who have difficulty choosing to those who face serious problems and are 'in danger of exclusion'.

The answer - for those with fewer problems - seems to lie in choosing the right education, completing it on time, and being able and willing to move wherever the jobs are; in this context, this refers to mobility within Finland and to urban areas. There are some educational paths that guide young people into the wrong careers, and some that steer them towards the right ones.

The list of bad career choices includes media and information, ICT, tourism, the beauty industry, arts and crafts, and electricity mechanics and automation technology. The good career choices are in social and healthcare, medicine, cleaning services, and machine, metallurgic and energy technology (MF 2010, 33-34).

Education seems to be the answer, as local government should provide education that is in sync with labour market needs. Previously, local governments - because the financing of their schools depends on how many students they have - were ready to offer educational choices that young people wanted, such as in media, tourism, arts and culture (Ministry of Finance 2009). Young people who were trained to be self-confident individual subjects were eager to take their place in the creative class (Allen \& Hollingsworth 2013). It is hinted here that they should be more realistic in their choices.

The dependency ratio has been growing in Finland for a long time, and the younger generation is now smaller than the older. We need taxpayers, and above all we need people to take care of the ageing population. Society needs workers to take care of elderly, leaky bodies (see Wolkowitz 2011). So society still needs those whose labour value is counted by the hour (Adkins 2009). We need those who are willing to spend hours in low-paid jobs in the service 
sector. Society needs those who can settle down in small villages as easily as in big cities, although most service sector vacancies are in those cities, where it is expensive to live. Mobile workers and older generations need local workers, people who work for the future of the others (see Thrift 2005).

Even though this document is also written in a gender-neutral manner, we know that most of the jobs mentioned as preferable are highly gendered: care workers are mostly women, and technicians mostly men. In Finland, occupational gender segregation is resilient (Official Statistics Finland 2015). However, in the list of educational routes to be avoided, there are also gendered choices, such as the beauty industry, arts and crafts, ICT, and electricity and automation. The paper addresses young men and women equally, although the care sector is somewhat emphasised in this discourse.

While young people can, in the learning mobility context, be quite old (up to 35), in the context of employment they are 15-24 years old. This is, of course, because PhD students are seen as 'young' since they 'study'. Choosing the right education, however, is seen as happening earlier. Nonetheless, the main concern is about young people seeking or already in vocational training, since they are more likely to be unemployed (MF 2010, 26-27).

As Wallace and Bendit (2009) write, different ministries have their own emphases concerning youth politics. We might see the Ministry of Finance as a key player in the politics of austerity in Finland. This ministry presents youth as a resource not for global competition, but for national maintenance. Its guidance is about not empowerment but restriction. Employability is not the correct term here; this is more about skills, qualifications and a willingness to do dirty and/or hard work, rather than having the right personality and an impressive CV full of extracurricular activities. Young people are expected to grow into working citizens (Pehkonen 2013).

The characteristics of youth with the right skills are somewhat different from those who are mobile: they can have local attachments, but have to be ready to move for their education; they should follow rules - the regulations are for them, as deterrents as well as incentives; and they should grow up to be proper Finnish citizens. As adults they will be skilled workers in the service of our care sector or infrastructure. These are characteristics that suit the category 'working class' better than 'middle class'. Care suits women, and maintenance work suits men. 


\section{Marginalisation: citizenship skills}

Growing youth unemployment is an obvious key concern when social exclusion is discussed. Marginalisation and underprivileged young people have even cropped up in discussions within mobility documents (EC 2010), as well as in documents on labour shortages (Ministry of Finance 2010). In Finland and the EU, the main policy to tackle the problem is the Youth Guarantee (Ministry of Employment and the Economy 2013; EC 2013).

The Youth Guarantee is a social innovation in which "early intervention and activation are key' (EC 2013). The idea is that agencies cooperate in order to reach young people (aged under 25 or 29) who are at risk of exclusion from work and education. The Finnish scheme is presented as a success story by the EC (ibid.).

Interestingly, the discourse of marginalisation seems to have hijacked the traditional tools of youth work. In the context of marginalisation, workshops and other forms of youth work appear to be forms of 'activation'. This fluctuation is not a new or surprising phenomenon; during its history, Finnish youth work has always borne different meanings, aims and functions, reflecting hegemonic ideologies of the times (Nieminen 2013). Obviously, actors in different policy fields also have their own angles on youth work, and they thus attribute it with their own aims (see Wallace \& Bendit 2009). My claim is that this shift has impoverished the perception of youth work and workshops, the picture of young people using these services and young unemployed people.

Young people who are unemployed and lack professional competence after basic education or upper-secondary school are offered vocational training by the ministry. Agents who offer apprenticeship programmes are offered more resources as well as youth workshops and youth outreach workers. Higher education does not seem to be on offer, even though those with upper-secondary (high-school) qualifications are included.

The workshops offer a place for young people to learn life skills, grow into adulthood and get hands-on experience of work, encouraging and helping them to seek further training (Ministry of Employment and the Economy 2013, 8-9.). 
A workshop offers the young person an opportunity for guided and supported work, and a tailored path to education, finishing education in cooperation with the education provider, or becoming employed in the open labour market.

The purpose of youth outreach work is to help under-29-year-olds who are outside education or the labour market, and who need support to access public-sector services or to commit to an available service, or who are at risk of social exclusion. (Ministry of Employment and the Economy 2013, 8-9.)

According to the document, these young people need to get hands-on experience of work and grow into adulthood. These measures offer a mixture of support and empowerment, whereas the measures to encourage people into education are mainly deterrents (if you do not apply, you will not get unemployment benefits).

This Youth Guarantee as an answer to the discourse of youth marginalisation is similar to discourses about youth vulnerability and at-risk-youth mentioned earlier (Kelly 2006; Foster \& Spencer 2011; McLeod 2012). Early intervention and activation (incentives and deterrents) are the measures used (Foster $\&$ Spencer 2011). The discourse also presupposes vulnerability, which means that the young people talked about are not seen as fully competent citizens. This legitimises the interventions and may also reduce their rights as citizens (McLeod 2012).

In these documents, marginalisation concerns mainly lower-class young people who might work in low-paid jobs in the bodily, social and technical maintenance of society. 'Hands-on experience' seems to refer to the working-class ideal of manual labour. These young people might be part of the answer to the problem of an ageing society. However, it is also hinted that even smaller signs of integration into society would be welcome, such as being a competent consumer of public-sector services.

In Finnish and European contexts, marginalisation is usually related to immobility - both social and spatial. If the young people that the Ministry of Finance is worried about are moving in the wrong directions, marginalised young people are presented as those who are stuck in their locality and its problems. If other young people acquire skills and invest in themselves, the targets of the Youth Guarantee are helped, pushed and offered alternative routes to employment. They are even supported 'to access public-sector services or to commit to an available service' (TEM 2013). 
These young people who are without work and education are recognised as people without life skills, and needing help and support. This large component of the youth population is presented as incapable of making choices and acting as proper, able-bodied and able-minded individuals. Actually, the group that the Youth Guarantee concerns is quite large and heterogeneous. There are those who have earned high-school diplomas but have not got into the universities or colleges of their choice; there are those who want to take a year off; and those who have physical or mental health problems. The measures proposed in the Youth Guarantee may help some and be a deterrent for others. They may also place many people in the category of 'at-risk youth', especially when the emphasis is on early intervention, which is arguably a labelling rather than a helping device (Foster \& Spencer 2011). Furthermore, some people, and some forms of marginalisation, may be left without help, for instance if the cause of exclusion is the 'burnout' of those with education - who are often women.

When marginalisation is defined as being without work and without vocational training, it is a men's problem - or an immigrants' problem (Myrskylä 2011). However, this is not the only way to define the term. Social exclusion can also occur after one has gained an education, due to psychological problems, for instance. This broader definition would include more women.

Those who are at-risk are characterised as not full adults, and as lacking in some basic skills, and their best possible future is to get hands-on work (by implication, in material rather than immaterial labour). They are becoming-a-citizen, in the best-case scenario. These are not middle-class but-lower class characteristics. They could be either women or men, but the problems presented are usually seen as men's problems. They are so immobile that they have to be reached in their own localities and homes.

\section{Conclusions and discussion}

Different futures seem to be assigned to different young bodies. Young people are divided into those who have potential, those who will take care of others' needs, and those who are at risk of marginalisation. Being able-bodied differs according to the context. Being a mobile body requires an ability to distance oneself from relations with other bodies. Being an employed body requires movement and investment in education, although not at too high a level. Being an included body, a citizen, requires an ability to use the services that society offers. Ideal future bodies are also different: for example, mobile workers, potential brain- 
drain workers, employed care workers, those who take care of the infrastructure, and citizens who accept the terms of inclusion and integration.

While on the surface level young people are treated as a homogeneous group, their divisions relate to their gender and class positions. Gendered and classed ways of attaching to other bodies, places, employments and professions are reproduced and valued in the documents. It is also clear that the most optimistic visions are not for all. The Ministry of Finance (2010) actually discourages young people from aiming too 'high', from aspirations to creative and mobile work. Additionally, while these young people are told to follow the rules and complete their education on time, others targeted in mobility discourse are told that they should not take the rules literally, since it is better for their employability to take a year off and travel than get to their qualifications by a deadline. Cultural resources help when you play the games of education and employability: you have to know which rules to follow, which attachments are not good for you, and in which worlds your kind of body will find footing with ease.

Young people are seen as a resource for others, for future economic growth and global competition, and for the maintenance of our society. They are also seen as a problem - if they do not learn life skills and become included. Neoliberal capitalism is in Finland slowly replacing Nordic social-democratic capitalism and its values. At the level of documents and youth policies this means that while many explicit aims are inclusive and social democratic, neoliberal rationality is creeping into document texts, changing the tone to a more exclusive and competitive one. Furthermore, when old institutions and youth policy tools such as workshops are integrated into the new discourse and new ideological context, at least on paper, their (ideological) functions can change.

\section{This work was supported by the Academy of Finland under Grant [number 137968]; and the Kone Foundation.}

\section{References}

Adkins, Lisa. 2004. 'Reflexivity: Freedom or Habit of Gender.' In Feminism After Bourdieu, edited by Lisa Adkins and Beverley Skeggs, 191-210. Oxford: Blackwell. 
Adkins, Lisa. 2008. 'From Retroactivation to Futurity: The End of Sexual Contract.' NORA Nordic Journal of Feminist and Gender Research 16 (3): 182-201.

Adkins, Lisa. 2015. 'What Can Money Do? Feminist Theory in Austere Times.' Feminist Review 109 (1): 31-48.

Allen, Kim, and Sumi Hollingworth. 2013. "Sticky Subjects" or "Cosmopolitan Creatives"? Social Class, Place and Urban Young People's Aspirations for Work in the Knowledge Economy.' Urban Studies 50 (3): 499-517.

Borlagdan, Joseph. 2015. 'Inequality and 21-Year-Olds' Negation of Uncertain Transition to Employment: a Bourdieusian Approach.' Journal of Youth Studies 18 (7): 839-854.

Bourdieu, Pierre. 1990. The Logic of Practice. Stanford: Stanford University Press

CIMO. 2009. Green Paper on Learning Mobility. Contribution by CIMO, Centre for International Mobility, Finland, 12/2009.

http://cimo.fi/instancedata/prime product julkaisu/cimo/embeds/cimowwwstructure/180 79 green-paper-on-learning-mobility-CIMO.pdf

Clarke, John and Janet Newman. 2012. The alchemy of austerity. Critical Social Policy 32 (3): 299-319.

Coleman, Rebecca. 2016. ‘Austerity Futures: Debt, Temporality and (Hopeful) Pessimism as an Austerity Mood.' New Formations 87: 83-101.

van Dijk, Teun. 1993. 'Principals of Critical Discourse Analysis.' Discourse \& Society 4 (2): 249-283.

Dumitru, Speranta. 2014. 'From "Brain Drain" to “Care Drain”: Women's Labor Migration and Methodological Sexism.' Women's Studies International Forum 47 (B): 203-212.

Erola, Jani. 2012. 'Family Background and the Life Cycle Effects of Father's Class and Income.' In Social Stratification: Trends and Processes, edited by Paul Lambert, Roxanne Connelly, Robert M. Blackburn and Vernon Gayle, 85-99. Farnham: Ashgate.

European Commission (EC). 2008. New Skills for New Jobs. http://ec.europa.eu/social/main.jsp?catld=568 
European Commission (EC). 2009. Green Paper on the Learning Mobility of Young People. Brussels, 8.7.2009 COM (2009) 329 Final. http://eurlex.europa.eu/LexUriServ/LexUriServ.do?uri=COM:2009:0329:FIN:EN:PDF

European Commission (EC). 2010. Youth on the Move: An Initiative to Unleash the Potential of Young People to Achieve Smart, Sustainable and Inclusive Growth in the European Union. Luxemburg: Publications Office of the European Union. doi 10.2766/69901

European Commission (EC). 2013. Youth Guarantee.

http://ec.europa.eu/social/main.jsp?catId=1079

Foster, Karen Rebecca, and Dale Spencer. 2011. 'At Risk of What? Possibilities over Probabilities in the Study of Young Lives.' Journal of Youth Studies 14 (1): 125-143.

France, Alan. 2007. Understanding Youth in Late Modernity. Maidenhead: Open University Press.

Garam, Irma. 2014. Tietoa ja tilastoja -raportti 2/2014: Kansainvälinen liikkuvuus yliopistoissa ja ammattikorkeakouluissa 2013. Helsinki: CIMO.

Harvey, Lee. 2001. 'Defining and Measuring Employability.' Quality in Higher Education 7 (2): 98-109.

Hoffman, David. 2009. 'Changing Academic Mobility Patterns and International Migration: What Will Academic Mobility Mean in the 21 st Century?' Journal of Studies in International Education 13 (3): 347-364.

Julkunen, Raija. 2001. Suunnanmuutos. 1990-luvun sosiaalipoliittinen reformi Suomessa. Tampere: Vastapaino.

Kantola, Anu. 2006. 'Suomea trimmaamassa: suomalaisen kilpailuvaltion sanastot.' In Uusi jako. Miten Suomesta tuli kilpailukyky-yhteiskunta? edited by Risto Heiskala and Eeva Luhtakallio, 156-178. Helsinki: Gummerus.

Kelly, Peter. 2006. 'The Entrepreneurial Self and "Youth-at-Risk": Exploring the Horizons of Identity in the Twenty-First Century.' Journal of Youth Studies 9 (1): 17-32.

McCabe, Earl. 2011. 'Depressive Realism: An Interview with Lauren Berlant.' Hypocrite Reader 1 (5). http://hypocritereader.com/5/depressive-realism 
McDowell, Linda. 2012. 'Post-Crisis, Post-Ford and Post-Gender? Youth Identities in an Era of Austerity.' Journal of Youth Studies 15 (5): 573-590.

McLeod, Julie. 2012. 'Vulnerability and the Neo-liberal Youth citizen: A View from Australia.' Comparative Education 48 (1): 11-26.

McNay, Lois. 1999. 'Gender, Habitus and the Field: Pierre Bourdieu and the Limits of Reflexivity.' Theory, Culture \& Society 16 (1): 95-117.

Ministry of Employment and the Economy. 2013. Nuorisotakuun tavoitteet ja sisältö. Muistio 12.3.2013 [Youth guarantee: Content and Aims. Memorandum attached to a letter to locallevel agents]. Helsinki: TEM.

http://www.nuorisotakuu.fi/files/36290/Nuorisotakuun_tavoitteet_ja_sisalto__Kirje_nuorisotakuun_alueellisille_ja_paikallisille_toimijoille.pdf Ministry of Finance. 2010. Nuoret työmarkkinoilla. Miten nuorten työllistymistä tulisi edistää? [Labour Markets of the Young: How Could Youth Employment Be Enhanced?] Valtionvarainministeriön julkaisuja 14/2010. Helsinki: Ministry of Finance. http://www.vm.fi/vm/fi/04_julkaisut_ja_asiakirjat/01_julkaisut/08_muut_julkaisut/20100224 Nuoret/Nuoret_tyoemarkkinoilla.pdf

Morley, Louise. 2001. Producing new workers. Quality, equality and employability in higher education. Quality in Higher Education 7 (2): 131-138.

Myrskylä, Pekka. 2011. Nuoret työmarkkinoiden ja opintojen ulkopuolella. Työ- ja elinkeinoministeriön julkaisuja. Helsinki: Työ- ja elinkeinoministeriö.

Nieminen, Juha. 2013. 'Theories and Traditions Informing Finnish Youth Work'. In Reappraisals: Essays in the History of Youth and Community Work, edited by Ruth Gilchrist et al., 73-88. Dorset: Russell House Publishing.

Nikunen, Minna. 2013. 'Nuoret liikkuvat. Eliitit kannustavat.' In Liikkuva maailma. Liike, raja, tieto, edited byMikko Lehtonen, 215-231. Tampere: Vastapaino.

Nikunen, Minna. 2016.'Liikkuvuus nuorten työmarkkinoiden pääomana.' In Ruumiillisuus ja työelämä. Työruumis jälkiteollisessa taloudessa, edited by Jaana Parviainen et al., 76-95. Tampere: Vastapaino. 
Nivalainen, Satu. 2010. Essays on Family Migration and Geographical Mobility in Finland. Helsinki: PTT Publications.

Official Statistics Finland. 2013. Alussa asutaan yksin tai kaksin-lopussa uudestaan yksin. Helsinki: Statistics Finland.

Official Statistics Finland. 2013. Migration. Helsinki: Statistics Finland.

Official Statistics Finland. 2014. Työvoimatutkimus [Labour Force Research]. Helsinki: Statistics Finland. https://www.stat.fi/til/tyti/2014/06/tyti_2014_06_2014-07-22_fi.pdf Official Statistics Finland. 2015. Professional Differentiation by Sex Continued in 2013. Helsinki: Statistics Finland.

Paananen, Merja, Tiina Ristikari and Marko Merikukka. 2012. Lasten ja nuorten hyvinvointi. Kansallinen syntymäkohortti 1987 -tutkimusaineiston valossa. Raportti 52/2012. Helsinki: National Institute for Health and Welfare.

Pehkonen, Leila. 2013. 'Saako työntekijäkansalaista sivistää?’ In Ammatillinen koulutus ja yhteiskunnalliset eronteot, edited by Brunila, Hakala, Lahelma and Teittinen, 31-46. Helsinki: Gaudeamus.

Reay, Diane. 2004. 'Gendering Bourdieu's Concept of Capitals? Emotional Capital, Women and Social Class.' In Feminism After Bourdieu, edited by Lisa Adkins and Beverley Skeggs, 57-74. Oxford: Blackwell Publishing.

Robertson, S. L., and I. R. Dale. 2013. 'The Social Justice Implications of Privatisation in Education Governance Frameworks: A Relational Account.' Oxford Review of Education 39 (4): 426-445.

Ruotsalainen, Kaija. 2013. Väestö vanhenee - heikkeneekö huoltosuhde? Helsinki: Statistics Finland.

Sacks, Harvey. 1972. 'An Initial Investigation of the Usability of Conversational Data for Doing Sociology.' In Studies in Social Interaction, edited by David N. Sudnow, 31-74. New York: Free Press.

Skeggs, Beverley. 2004. Class, Self, Culture. London: Routledge.

Thrift, Nigel. 2005. Knowing Capitalism. London: Sage. 
Tolonen, Tarja. 2005. 'Locality and Gendered Capital of Working-Class Youth.' Young:

Nordic Journal of Youth Research 13 (4): 343-361.

Vuorinen-Lampila, Päivi. 2014. 'Gender Segregation in the Employment of Higher

Education Graduates.' Journal of Education and Work. DOI:10.1080/13639080.2014.934788

Walby, Sylvia. 2011. The Future of Feminism. Cambridge: Polity Press.

Wallace, Claire, and Rene Bendit. 2009. 'Youth Policies in Europe: Towards a Classification of Different Tendencies in Youth Policies in the European Union.' Perspectives on European Policies and Society 10 (3): 441-458.

Watson, Rod. 1983. 'Presentation of Victim and Motive in Discourse.' Victimology 8 (1/2): $31-52$.

White, Rob, and Johanna Wyn. 2013. Youth and Society. South Melbourne: Oxford University Press.

Wolkowitz, Carol. 2011. 'The Organizational Contours of "Body Work”.' In Handbook of Gender, Work, and Organization, edited by Emma L. Jeanes, David Knights and Patricia Yancey Martin, 177-190. Southern Gate: Wiley.

Yoon, Kyong. 2014. 'Transnational Youth Mobility in the Neoliberal Economy of Experience.' Journal of Youth Studies 17 (8): 1014-1028.

\footnotetext{
' Austerity measures are directed to the public sector, while the hope of the economic growth and confidence towards the future is placed in the private sector. This creates the 'new landscapes of inequality' since cuts are unevenly distributed. For instance, female unemployment is affected by the cuts on the public sector. (Clarke \& Newman 2012.) However, I am not in this paper examining the direct effects of the cuts but only the reflections of these ideas on expectations surrounding young people and youth policies.

ii This focus on employment and education gives the EU a somewhat more neoliberal voice than would be the case if the issues of human rights were being inspected. The documents of the Commission's youth unit are not included in the data, since they deal with youth issues on a more general level than those selected.
} 